\title{
Vietnamese consumers' preferences for traceable food and safety attributes: The case of water spinach
}

\author{
HUY DUC DANG ${ }^{a}{ }^{*}$, THUYEN THI PHAM ${ }^{a}$, GIANG THANH TRAN ${ }^{\text {a }}$, AU HAI THI DAM ${ }^{\text {a }}$ \\ TRA MY THI NGUYEN ${ }^{a}$ \\ a Economics Faculty, Nong Lam University, Ho Chi Minh City, Vietnam
}

\begin{abstract}
A R T I C L E I N F O
A B S T R A C T

Received: Mar 1, 2019

Revised: Jun 21, 2019

Accepted: Jul 17, 2019

Available online

JEL classification:

D12, D71

Keywords

Consumer preferences;

Food safety;

Traceability;

Water spinach.

The government struggles to fight escalating food safety issues in Vietnam. However, government measures yielded little evidence of improvement to domestic food safety. For that reason, consumers lower their trust in the government. The current market context, and low trust towards the government left consumers to count on their own judgement for the sake of their own food safety. This study applied choice experiment method based on Lancastrian consumer theory and random utility theory to elicit consumers' preferences on traceable safe foods and the perception regarding food safety. The impact of food safety related attributes was identified in the order of decreasing magnitude: Freshness, label, traceability, certification, and price. Results suggested that Vietnamese consumers adhered food quality to food appearance (i.e. freshness) and made judgement with such perception. This paper also highlighted a noticeable reverse impact of the level of food certification on consumer preferences toward safe choices, which contributed to the current food safety situation in Vietnam. The reason was expected to be trust issues in the government, the impact of food safety context, and consumers' false perception of food safety. To enhance trust, food traceability appears
\end{abstract}

\footnotetext{
* Corresponding author.

Email: ddhuy@hcmuaf.edu.vn (Huy Duc Dang), phamthuyen@hcmuaf.edu.vn (Thuyen Thi Pham), tthanhgiang@hcmuaf.edu.vn (Giang Thanh Tran), haiaudam@hcmuaf.edu.vn (Au Hai Thi Dam), nttmy.nlu@gmail.com (Tra My Thi Nguyen).

Please cite this article as: Dang, D. H., Pham, T. T., Tran, G. T., Dam, T. H. A., \& Nguyen, T. T. M. (2019). Vietnamese consumers' preferences for traceable food and safety attributes: The case of water spinach. Journal of Asian Business and Economic Studies, 26(S02), 47-70.
} 
to be an indispensable and potential instrument. Besides, traceability information should be addressed via food label precisely to augment visual inspection as well as to increase its effectiveness. Additionally, consumers are willing to pay a price premium for traceable products, thus inducing suppliers to participate in food traceability. Nevertheless, the government must play a more proactive role in market supervision and education to facilitate the development of food traceability.

\section{Introduction}

Vietnam was overwhelmed with food safety issue warnings on every media channel (World Bank, 2017a). From 2014 to 2015, there were 370 outbreaks of food-borne diseases (FBD) in Vietnam, which involved 10,000 incidences that resulted in the death of 66 people. The actual results could have been more severe, as World Bank (2017b) announced that only a small percentage of FBD was captured by the national surveillance system (in less than $0.1 \%$ ). Based on several sources, World Bank (2017b) estimated that hospitalization cost from food-borne diarrhea in Vietnam was around USD 6 million (noted that hospitalization represents only a small portion of the total cost of FBD). Besides, the burden of unsafe foods was commonly associated with the rapid growth rate of cancer cases, even though unhealthy living styles (e.g. smoking, alcohol abuse) or environmental factors were also the determinants.

According to World Bank (2017a), the government responded with several courses of action. The government took actions in strengthening legislation and regulation, upgrading and certifying food chains, introducing good agriculture practice (GAP), modernizing retail, public information, and increasing exports. However, government measures yielded little evidence of improvement in domestic food safety. Literature reviews pointed out the failure of government measures for several reasons. First, low trust resulted in the disadoption of products with government certification stamps. Results were found in the case study of avian influenza outbreak in 2009 (Ifft et al., 2009a). Ifft et al. (2009b) confirmed trust issue with accessing safety-labeled and traceable free-range chickens in Ha Noi city, as households gave the lowest trust score (mean 5.28 out of 10) to market inspectors. The government implemented VietGap (Vietnamese good agriculture practice) in 2009 hoping to foster the modern agri-food system in Vietnam. Nonetheless, vegetable production volume of Viet Gap accounted for only $1.1 \%$ of total vegetable production (GSO, 2016). In fact, there was little evidence that participation in GAP made food safer or helped to capture extra profit (Nguyen-Viet et al., 2017). Indeed, after more than 10 years of major efforts and investments of the government and market actors, safe production and distribution systems have only secured less than $10 \%$ of the market share (World Bank, 2017a). Regarding modernizing retails by replacing wet markets with supermarkets, this policy delivered a contrasting outcome as this rigid approach failed to adapt to the differences in shopper population, resulted in driving a large group of shoppers into informal vending structures 
(Wertheim-Heck et al., 2015), as well as unable to ameliorate food safety (Fahrion et al., 2013). Food safety and hygiene propaganda campaigns were common to enhance public awareness regarding food safety issues. However, this measure failed to inform consumers how to safeguard their households from contaminated food; instead, consumers chose to boil food as a popular method for food detoxification (World Bank, 2017b).

To cope with food safety issue and gain back consumers' confidence, food traceability emerged as a very potential problem solver. A rigorous definition of traceability was provided by EC regulation 178/2002 as "the ability to trace and follow a food, feed, food producing animal or ingredients, through all stages of production and distribution" (European Parliament, 2002). In designing a general framework and experimental evidence for traceability of food products, Regattieri et al. (2007) came to a conclusion that traceability was an indispensable instrument in obtaining the market consensus by providing inevitable benefits such as supply chain optimization, product safety, and market advantages. Acknowledging the importance of food safety, the Vietnamese government released the food safety law in 2010. Within the scope of the law, latter in Circular 74/2011/TTBNNPTNT (MARD², 2011a) and Circular 03/2011/TT-BNNPTNT (MARD, 2011b), traceability is defined as "the ability to monitor, recognize a unit of product through every stage of the process of production and trading". Also, the follow-up Circular 11/2017/TTBNNPTNT (MARD, 2017) amended previous Circulars to strengthen the role of government's market inspectors. The purpose of the law was to empower traceability, and to withdraw unsafe products, which regulated that production and trading units must build their own traceability system with required minimum information for traceability. Having a traceability system is mandatory by the law; however, its characteristics are up to builders' decisions. The government only required a minimum information for traceability, in general, not in specific, for any products. In addition, building a central database to manage the entire chain was not constrained by the law. Thus, traceability information in Vietnam was very fragmented and decentralized into different hands, mostly in private sector from big players included Smartlife, VNPT check, Vinacheck, Agricheck, Traceverified, and Icheck. Asymmetric information was popular among traceability system providers due to the unavailability of detail requirements for such information under the law, which corrupted greatly the transparency of those systems. Moreover, traceability stamps were prone to be tampered by counterfeits, which lower consumers' confidence in the traceability system. Regardless of mentioned conditions, consumer preferences on traceable food remains unknown, especially in the case of Vietnam, where consumers' trust and confidence regarding safe food deteriorated regardless of the government efforts to regain them (World Bank, 2017a). This raised two research questions:

- What are consumer preferences on traceable food with safety attributes in Vietnam?

- How food traceability is perceived in the context of current food safety issues?

\footnotetext{
${ }^{2}$ MARD stands for Ministry of Agriculture and Rural Development
} 
On this subject, related studies from developing countries with similar characteristics of the food safety crisis were limited. On the other hand, literatures on such matter were abundant in developed countries, such as USA, Canada, Spain and Italy. However, the application of findings from developed countries to developing countries has not been verified yet (Wu et al., 2015), especially when most of the focus of researches in developed countries was meat, applicability to vegetable remained a question to attest. Given a heighten food safety issue in Vietnam, it is important to shed light on consumer preferences, and food traceability perception for the development of food safety measures such as food traceability systems.

This study conducted a structural survey in Ho Chi Minh City, Vietnam to determine consumers' perceptions by examining key factors that affect consumers' choices for safetyrelated attributes. Results from this research can be applied to countries with similar characteristics, especially developing and under-developed countries. Also, the results from this study will contribute to the global understanding of consumers' decision-making to safeguard their own safety in a situation in which all government intervention seems insufficient and not yet effective.

\section{Literature Review}

Studies on consumer preferences regarding food safety were abundant in developed countries. However, there are shortcomings in the application of those results to developing countries, due to differences in consumer preferences in terms of product types, geolocation, and current food safety context. In the study of factors affecting consumers' willingness to pay for certified traceable food in Jiangsu Province of China, Wu et al. (2012) reported the significant number of consumers $(62 \%)$ were willing to pay a price premium for traceable food, which was much higher than that of developed countries such as the United States, Canada, and Spain. One of the suspected reasons was the different sample commodities used between those studies, as Wu et al. (2012) used Chinese green vegetable, while fellow researchers from developed countries used red meats. Another reason originated from the context of raising anxiety about food safety incidents among Chinese consumers. To sum up, consumer preferences across countries vary in terms of cultural and national differences (Wu et al., 2015). Further, in the context of great anxiety regarding food safety (i.e. risk perception), consumers were urged to pay a price premium for the food traceability system (Ortega et al., 2011; Wu et al., 2012).

Regarding consumers' preferences and perception on food safety and traceability, key influential factors were identified, including product price, certification and label, traceability attribute, freshness, social economic and demographic characteristics. For price, Ortega et al. (2011) used price to identify price sensitive consumers, of which concluded that even when Chinese consumers concerned about food safety, their willingness to pay extra for food safety attributes varied upon their income. Also, Röhr et al. (2005) pointed out that consumers tended to associate food safety assurance (i.e. food traceability) with higher 
prices. Consistent results among studies revealed that price coefficient was always expected to negatively relate to consumer choice (Lu et al., 2016; Ortega et al., 2016; Wu et al., 2016).

In terms of certification and label, one of the most popular ways to communicate food safety information was via labelling. Verbeke (2001) shed light on traceability information and quality certification, as an approach to regenerate consumer confidence in food safety. The existence of quality and safety related labels on food products provided a sense of control for consumers (van Rijswijk et al., 2008). Also, the physical presence of information on product labels was preferred to be precise and concise, which drawn consumers interest in traceability based assurance of quality (Hobbs et al., 2005), but not the technical information used (Gellynck \& Verbeke, 2001). Thus, the traceability technology should not be consumers' concerns but rather the content it is delivering. This was in accordance with findings of Giraud and Halawany (2006) that consumers paid less attention for modern traceability technology (e.g. RFID tags) and preferred on-product written information or simple labels. Similar to developed countries, the Vietnamese government has a constantly improving institutional framework regarding food labelling. Decision 178/1999/QĐ-TTg (Government, 1999) was first released to regulate the labeling of domestic and export products. The newest Decree 43/2017/NĐ-CP (Government, 2017) on product labelling was effective on June 1, 2017. Unfortunately, government implication and monitoring capacity remained a problem. Many false labelling cases were discovered by the public prior to the interference of government market inspectors, which lowered consumers trust and confidence on the government (World Bank, 2017a). As a result, consumers did not take into serious consideration products with government certification stamps (e.g. VietGap). This contrasted the situation in China, where people trusted government certification and even third-party certification (non government-controlled) (Ortega et al., 2011; Wu et al., 2015).

Next, traceability was the most preferred solution to food safety embraced widely by the scientific community. Van Rijswijk and Frewer (2008) showed the connection between consumer confidence in food safety and effective food traceability systems, which interpreted consumer perceptions on a sense of control from food chain actors. There was no common consensus for what specific types of products needed traceability. To be exact, consumers from different segments perceived quality and safety differently, usually associated with their preferred products (Viaene et al., 2000; van Rijswijk \& Frewer, 2012). Van Rijswijk et al. (2008) also found that traceability may carry more weights in the case of fresh produce, such as meat or fish, than fruit and vegetables due to more severe health consequences in contaminated incidents.

Label and traceability seem collaterally related to best serve the interest of the consumers. Van Rijswijk and Frewer (2012) found that consumer preferences varied on the communication of traceability. However, the salient point agreed upon by the majority of consumers was that the information regarding traceability should be in a precise and concise form. Moreover, the information must be presented on the product, which facilitates an instant visual inspection. Barcode scanner or ICT (information communication technology) based are less of a prefered information retrieving method. Besides, traceability served best 
to deliver great value to consumers in form of a bundle with other characteristics (e.g. animal welfare, extra food safety attributes) (Dickinson \& Bailey, 2002; Hobbs et al., 2005). Van Rijswijk et al. (2008) also suggested other characteristics to add to the bundle such as health, quality, control, origin, and naturalness (for organic products), as well as others that specifically serve different targeted consumers in different countries.

Visual appearance of food such as color, appearance, and freshness, was found to be a considerably important factor for consumers to judge product quality (Wu et al., 2015 ). In the study of consumer preferences toward beef labeling, Roosen et al. (2003) concluded that color played an important role for consumers in France and UK in a purchasing decision. In China, people determined product quality, especially fresh produce (e.g. pork), via judging the appearance, as found that "fresh looking" derived highest part-worth utility in terms of appearance (Wu et al., 2015).

For the past decades, social demographic characteristics has been researched to confirm their roles in aiding decision making. Popular research social demographic characteristics often included gender, age, education, occupation, and income, especially in studying consumer preferences. Nevertheless, the effects of the mentioned variables were inconsistent and varied case by case. For example, regarding income, Wu et al. (2012) and Angulo et al. (2005) confirmed the influence of income on consumer willingness to pay for traceable food. On similar research topic, same results were confirmed for the effect of age, while there were no statistically significant impacts of gender, education, and income in the case of dairy products (Chen et al., 2015). Jin and Zhou (2014) employed a binomial logit model to examine consumers' interests in food safety information via traceability systems. Except for the negative impacts of education and age, results showed that gender, marital status, and income were positively significant.

To sum up, available literatures have indicated a gap for more studies on consumers' perceptions of food safety attributes. Research knowledge from different geolocations was unlikely to be applicable for Vietnam or similar countries under current conditions. Further, most studies focused on meat as a sample commodity. As mentioned above, different customers from different segments perceived quality and safety differently, usually associated with their preferred products. For that reason, this study aims to investigate consumers' preferences toward food safety attributes via the case of traceable water spinach.

\section{Materials and Methods}

\subsection{Choice Experiment}

To elicit consumers' preferences for food safety attributes and related, the use of stated preference (SP) theory is massive. Regardless of how many researchers claimed to be in favor of nonhypothetical valuation methods, revealed preference theory (RP). (Gracia et al., 2011), SP provides many compelling reasons for its usage in case of estimating demand for new products, exogenous variables have little inconsistency, new explanatory variables are 
introduced, and the product does not exist in the real market (Louviere et al., 2000). The current market for traceability system in Vietnam is immature. There is no certain for real market data for the presented research topic. Thus, SP approach is a reasonable choice to provide insight into market responses to such matter. A choice experiment was designed for consumers. Common design stages for a choice experiment included selecting of attributes and assigning their levels, constructing choice cards and choice sets, and collecting data for analysis (Bateman et al., 2002).

\subsubsection{Selection of Attributes and Attribute Levels}

Based on literature reviews, five attributes were selected including price, label, certification, freshness, and traceability. Level settings for selected attributes were determined, base on several reasons (see Table 1).

Table 1.

Attributes and corresponding level settings used in choice experiment

\begin{tabular}{llll}
\hline Attributes & Unit & Traditional & Traceable \\
\hline Pricea (PRICE) $^{\text {USD/500g }}$ & 0.22 & $0.42 ; 0.51 ; 0.61$ \\
Product label (LABEL) & No & Yes; No \\
Certification (CERT) & No cert. & Vietgap; Globalgap; PGS \\
Freshness (FRESH) & Yes & Yes; No but edible \\
Traceability (TRACE) & No trace & level 1; level 2; level 3 \\
\hline
\end{tabular}

Note: ${ }^{\text {a }}$ exchanged rate as of August 2018: 1 USD = 23.065 VND;

Source: https://www.vietcombank.com.vn/exchangerates/

First, Carlsson et al. (2007) found that having price attributes in a choice experiment substantially influences consumer preferences and relative ranking of alternatives. In most choice experiment papers, experts often chose to collect real prices from retail transactions (de-Magistris \& Gracia, 2014; Gracia, 2014; de-Magistris \& Gracia, 2016; Wu et al., 2017). Price levels were set at $0.22 \mathrm{USD} / 500 \mathrm{~g}$, based on current market price for the baseline price of water spinach at the traditional market, at time of research. Water spinach at this price came with no packaging, no label, no food safety attributes, nor traceability information. For water spinach with retrievable traceability information via $Q R$ code, the study recorded common retail prices of 9,900 VND (0.42 USD), 11,000 VND (0.48 USD), and 17,000 VND (0.74 USD) per $500 \mathrm{~g}$ of water spinach at supermarkets and convenient stores such as Big C, Coopmart, Satrafood, and Vinmart. Price varied among stores based on brand and level of certification as Globalgap certified-products seem priced higher than Vietgap certifiedproducts, but not always. Mørkbak et al. (2010) suggested that the design of price should be taken with cautiousness because of choke price bias, setting the price level at which consumers are no longer interested in the product. However, deciding the choke price threshold requires more reasearch to confirm prior to conducting a choice experiment. Due to our financial and time constraints, the paper could not afford such research. Instead, the 
study chose the lowest price found for traceable water spinach as a base value of 0.42 USD/500g; two incremental levels were calculated at an additional $20 \%$ and $40 \%$ higher than the base value. In total, price was set at four levels in accordant with the traditional baseline, and three alternatives for three levels of traceability respectively. This price setting was expected to create the acceptable differences in prices enough for consumers to consider the additional benefits associated with a certain price threshold, but not too much that will trigger price bias. For the label attribute, a dummy variable was used (1: Label presence, 0: Label absence). Regarding certification attributes, most studies investigated levels, in general, such as government certification and third party certification (van Rijswijk \& Frewer, 2012; Wu et al., 2015; Wu et al., 2017). Instead, this study built four levels of certification namely No Trace, Vietgap, Globalgap, and PGS (Participatory Guarantee System for organic certified products), which already covered the categories of government and third party certification. Other globally well-known certifications such as EU organic or US. organic were excluded due to their unpopularity in local markets. Thus, the proposed setting was expected to facilitate consumer decision-making via local well-known food assurance trademarks. Next, freshness was included to investigate the impact of appearance on consumer preferences regarding food safety and traceability characteristics. According to Đỗ Kim Chung and Nguyễn Linh Trung (2015), freshness was the most interested factor among Hanoi shoppers, who shopped vegetable at wet-markets only, supermarkets only, or shopped at both. For brevity, freshness was investigated with two levels (1: Fresh, 0: No fresh but edible). Regarding level setting of traceability attributes, Golan et al. (2004) recommended that food safety information be communicated via three aspects included breadth, depth, and precision. Due to the complication of performing such practice in full, this study followed $\mathrm{Wu}$ et al. (2015) to investigate only the depth aspect of traceability information (i.e. forward and backward traceability). Three incremental levels of traceability used in this research were employed from the real practices of private providers such as Smartlife, VNPT check, Vinacheck, Agricheck, Traceverified, and Icheck (see Table 2 for details).

Table 2.

Traceability levels and detail explanation

\begin{tabular}{ll}
\hline Traceability & Detail information \\
\hline & 1. Product information: packaging date, product specification, storage time, \\
& instruction of use. \\
& 2. Producer information: name, country, province, contact address, phone \\
& number, fax number, email. \\
Level 1 & 3. Ingredient information: batch number, plantation information (farm code, \\
& farmer name, address, planting method).
\end{tabular}




\begin{tabular}{ll}
\hline Traceability & Detail information \\
\hline \multirow{2}{*}{ Level 2 1. Product information: packaging date, product specification, storage time, } \\
instruction of use. \\
2. Production process: product type, planting season, location, harvest season (in \\
batch), information of fertilizers used, crop protection, harvesting, processing and \\
packaging. \\
3. Distributor information: name, legal documents established, capacity of \\
production and distribution of goods. \\
1. Product information: packaging date, product specification, storage time, \\
instruction of use. \\
2. Producer information: name, country, province, contact address, phone \\
number, fax, email. \\
3. Distributor information: name, country, city, contact address, telephone \\
number, fax number, email. \\
4. Retailer information: name, country, city, contact address, telephone number, \\
fax number, email, consumer reviews of the products. \\
5. Consumers: send notice of product recall or product cancellation upon \\
detection of infection cases and refund mode.
\end{tabular}

\subsubsection{Construction of Choice Cards}

A combination of three attributes with three levels, two attributes with two levels resulted in a full factorial design of 108 alternatives $(3 \times 2 \times 3 \times 3 \times 2)$. It was impossible to survey respondents with such plenty profiles. Thus, the study implemented an orthogonal fractional factorial design (Addelman, 1972), using SPSS version 19.0, to generate twenty two uncorrelated calibration profiles (Bateman et al., 2002), of which four hold-out profiles were included to check the consistency of respondents. Table 3 shows a sample choice card designed to conduct the choice experiment.

\section{Table 3.}

A sample choice card

Question: Please select your most preferred option of water spinach below.

\begin{tabular}{lcc}
\hline Attribute & Option 1 & Option 2 \\
\hline Price & 0.22 (USD/500g) & 0.61 (USD/500g) \\
Product label & No & Yes \\
Certification & No & Viet Gap \\
Freshness & Yes & Yes \\
Traceability & No & Trace level 3 \\
\hline Please select the option you & $\square$ & $\square$ \\
prefer most & & \\
\hline
\end{tabular}

Note: A exchanged rate as of August 2018: 1 USD = 23,065 VND;

Source: https:/ /www.vietcombank.com.vn/exchangerates/ 


\subsection{Data Collection}

This study conducted surveys from June to July of 2018 at various locations in Ho Chi Minh City, including supermarkets, wet markets, convenience-grocery markets, and farmers' markets with high consumer traffic. Data were obtained via a structured questionnaire in the following order: (1) Introductory information (i.e., who we are and what the purpose of this survey is), (2) questions on social demographic characteristics, (3) questions to clarify consumers' knowledge regarding food safety (i.e., how respondents perceived current food safety issues, consumers' perception of safe vegetables, questions on popular vegetable certifications), and (4) choice cards.

Prior to conducting the survey, the questionnaire was pre-tested to confirm the comprehensiveness of the questions and of the choice experiment. The final version of the questionnaire was designed based on suggestions of modification from the pre-test. During collection of the surveys, participants were randomly selected. To enhance the randomness of the survey, each survey location was limited to between 8 to 10 interviews. A total of 20 locations were visited with the outcome of 170 surveys collected, of which 150 were valid for use in this study.

\subsection{Sample Description}

The statistical description of survey consumers is shown in Table 4 . The majority of consumers fell into the age group of 18-35 (76\%). Many possessed a university degree (71.3\%). The study prioritized collecting information from women (78\%) as they are the main decision makers on food purchases. However, only $51.3 \%$ of respondents were the main shopper of their family, which was consistent with the majority being of a younger age. For those who were not the main shopper for food, it is assumed that elder female members of their family, such as their mothers or grandmothers, could be the main shoppers. The marital status of the respondents was fairly equal between single $(50.7 \%)$ and married (49.3\%). Among the married respondents, 56.7\% had children under 18 in the family. Regarding food safety perception, $62 \%$ of all respondents acknowledged that the current food safety rate ranged from unsafe to absolutely unsafe. The most popular traceability system via the QR code seemed strange to them, with only $42 \%$ acknowledging its existence. Among consumers who were familiar with the QR code, only $21.3 \%$ actually used it. 
Table 4.

Socio-demographic characteristics, food safety and traceability perception of respondents $(\mathrm{n}=150)$

\begin{tabular}{|c|c|c|c|c|c|c|}
\hline Characteristics & Coding & Mean & $\begin{array}{c}\text { Frequence } \\
(\%)\end{array}$ & $\begin{array}{l}\text { Standard } \\
\text { deviation }\end{array}$ & Min & Max \\
\hline \multirow[t]{5}{*}{ Age } & & 1.9 & & 0.9 & 1 & 4 \\
\hline & $1=18-25$ & & 32 & & & \\
\hline & $2=26-35$ & & 44 & & & \\
\hline & $3=36-55$ & & 18.7 & & & \\
\hline & $4=$ Above 55 & & 5.3 & & & \\
\hline \multirow[t]{3}{*}{ Gender } & & 0.2 & & 0.4 & 0 & 1 \\
\hline & $1=$ Male & & 22 & & & \\
\hline & $0=$ Female & & 78 & & & \\
\hline \multirow[t]{7}{*}{ Education } & & 3.9 & & 0.8 & 1 & 6 \\
\hline & $1=$ Primary & & 2 & & & \\
\hline & $2=$ Secondary & & 2.7 & & & \\
\hline & $3=$ High school & & 10 & & & \\
\hline & $4=$ Tertiary & & 71.3 & & & \\
\hline & $5=$ Post Grad & & 12.7 & & & \\
\hline & $6=$ Otherwise & & 1.3 & & & \\
\hline \multirow[t]{3}{*}{ Marital status } & & 0.5 & & 0.5 & 0 & 1 \\
\hline & $0=$ Single & & 50.7 & & & \\
\hline & $1=$ Married & & 49.3 & & & \\
\hline \multirow[t]{3}{*}{ Children under 18} & & 0.5 & & 0.5 & 0 & 1 \\
\hline & $1=$ Yes & & 56.7 & & & \\
\hline & $0=\mathrm{No}$ & & 43.3 & & & \\
\hline \multirow{7}{*}{$\begin{array}{l}\text { Monthly Income } \\
\text { (million VND) }\end{array}$} & & 3.3 & & 1.5 & 1 & 6 \\
\hline & $1=$ less than 2 & & 14 & & & \\
\hline & $2=2-4.99$ & & 14 & & & \\
\hline & $3=5-9.99$ & & 34.7 & & & \\
\hline & $4=10-14.99$ & & 14.7 & & & \\
\hline & $5=15-19.99$ & & 10 & & & \\
\hline & $6=20$ and above & & 12.6 & & & \\
\hline
\end{tabular}




\begin{tabular}{|c|c|c|c|c|c|c|}
\hline \multirow[t]{3}{*}{ Main shopper } & & 0.5 & & 0.5 & 0 & 1 \\
\hline & 1 = Main shopper & & 51.3 & & & \\
\hline & $0=$ Otherwise & & 48.7 & & & \\
\hline \multirow[t]{3}{*}{ Know $Q R$ code } & & 0.4 & & 0.5 & 0 & 1 \\
\hline & $1=$ Yes & & 42 & & & \\
\hline & $0=\mathrm{No}$ & & 58 & & & \\
\hline \multirow[t]{6}{*}{ Safety perception } & & 2.3 & & 1 & 1 & 5 \\
\hline & $\begin{array}{l}1=\text { Absolutely } \\
\text { unsafe }\end{array}$ & & 19.3 & & & \\
\hline & $2=$ Unsafe & & 42.7 & & & \\
\hline & $3=$ No opinion & & 26.7 & & & \\
\hline & $4=$ Safe & & 6.7 & & & \\
\hline & $\begin{array}{l}5=\text { Absolutely } \\
\text { safe }\end{array}$ & & 4.66 & & & \\
\hline
\end{tabular}

\subsection{Binary Probit Model}

The binary probit model was used to estimate the probability of respondents' selections on traceable or traditional non-traceable water spinach. The model was estimated using Stata version 14.1. The binary probit model has been used in numerous studies regarding food traceability (e.g., Verbeke \& Ward, 2006; Liao et al., 2011). The Lancastrian consumer theory (Lancaster, 1966) and random utility theory (Luce, 1959; McFadden, 1973) set strong footholds for choice experiments. In the choice experiment, consumers were asked to select their most preferred choice cards with different bundles of attributes among different choice sets in a pairwise setting. Let $U_{i j}$ denotes the utility of respondent $I(i=1,2, \ldots, I)$ for alternative $j$ ( $j=0$ for traditional non-traceable, and $j=1$ for traceable water spinach). The random utility model can be written as:

$$
U_{i j}=x^{\prime}{ }_{i j} \beta^{\prime}{ }_{m j}+\varepsilon_{i j}
$$

where

$x_{i}^{\prime}$ are observable vectors denoting choice experiment attributes, food safety, and traceability perception of consumers: Price, product label, certification, freshness, traceability, age, gender, education, marital status, children under 18, monthly income (see Table 4). The study further added several variables to elaborate on how the current context in Vietnam impacts consumer decisions. For example, the variable, main shopper, was used to study the role of the main shopper on food selection regarding safety attributes. The variable safety perception will help to shed light on how decisions are made under a certain market condition (Wu et al., 2012; Jin et al., 2017). Regarding traceability, the study intended 
to grasp consumers' awareness of the current most popular traceability system, as Wu et al. (2011) recommended that strengthening consumers' awareness of the food traceability system increased acceptance of traceable products and affected purchasing preferences. Thus, the variable, know QR code, was used to fulfill such intention.

$\beta^{\prime}{ }_{m}$ denotes the vectors of estimated coefficients of independent variables in the model $(\mathrm{m}=1,2, \ldots, k)$. In the model, four additional variables were included for different purposes. The study used the dummy variable, main shopper, to investigate the difference in shopping behavior for traceable products between the main decision makers and others (Loureiro \& Umberger, 2007). The children under 18 dummy variable was also included to further investigate whether or not the presence of a minor influenced the consumption of food with safety assurance attributes (Wu et al., 2012). The variable, safety perception, in a Likert scale of 5 was expected to measure the impact of current context on buying behavior. The random error vector, $\varepsilon_{i j}$, was assumed with a normal distribution to measure errors and specification errors.

In the choice experiment, respondents were expected to select the preferred alternatives that maximized their utility (Louviere et al., 2000). The binary probit model was used to elicit comsumers' selection, whereas $Y_{i}=1$ (traceable option) and $Y i=O$ (traditional option). Thus, the probability of respondent $\mathrm{i}$ selecting to adopt profile $\mathrm{m}$ under choice set $\mathrm{t}$ is true for any $m \neq n$, inferring $U_{i m t}>U_{i n t}$, and:

$$
\begin{gathered}
\operatorname{Prob}\left(Y_{i}=1 \mid x_{i}^{\prime}\right)=\Phi\left(x_{i}^{\prime} \beta^{\prime}{ }_{m}\right) \\
\operatorname{Prob}\left(Y_{i}=0 \mid x_{i}^{\prime}\right)=1-\Phi\left(x_{i}^{\prime} \beta^{\prime}{ }_{m}\right)
\end{gathered}
$$

where

$\Phi$ is the cumulative distribution function of the standard normal distribution, which takes values of 0 or 1 . The parameters $\beta^{\prime}{ }_{m}$ were estimated using maximum likelihood. For interpretation of variables in the model, the marginal effect approach is preferred over the direct measure of the change in predicting probability in accordance with a unit change in the explanatory variable (Ngoc et al., 2016). The marginal effect of a change in variable $x_{i j}$ can be computed as the partial derivative of $\Phi$ with respect to $x_{i}$.

$$
\frac{\partial \Phi\left(x_{i}^{\prime} \beta_{m}\right)}{\partial x_{j}}=\Phi\left(x_{i}^{\prime} \beta_{m}^{\prime}\right) * \beta_{m}
$$

\section{Results and Discussion}

The regression results of estimated models are presented in Table 5. This paper also estimated model 2 to explore how respondents' demographic characteristics (e.g., gender, age, education, income) impact their demand for traceability and certification attributes. Moreover, model 2 also investigates whether consumers' knowledge of the current context of food safety would sway their food purchasing decision. Model goodness-of-fit tests 
between two models were fairly indifferent. The Pseudo $\mathrm{R}^{2}(0.126)$ in model 1 and $(0.135)$ in model 2 are relatively low, corresponding with an overall corrected predition rate of $69 \%$ and $69.26 \%$, respectively, at a $1 \%$ significance level. Despite low $\mathrm{R}^{2}$, the results from this study are still useful in terms of providing knowledge regarding consumers' preferences because most of the explanatory variables in the models were significant at $1 \%$. Models 1 and 2 predicted approximately $60 \%$ of consumers favoring traceable products with binding safety attributes, which was slightly higher than what was observed $(59.56 \%)$ in the experiment. This is very promising for the future uptake of products with traceability attributes.

In model 1, all parameters were statistically significant except children under 18. Similar to $\mathrm{Wu}$ et al. (2012), the role of children under 18 was found to be insignificant in both models. Model 1 indicated that freshness and product label attained the highest coefficients. The dummy product label suggested that consumers were $15 \%$ more willing to adopt a traceable product with a label than one without a label. This confirmed the findings of van Rijswijk et al. (2008) that the presence of a food label gives a sense of control and best serves consumers' needs by providing a visual inspection (van Rijswijk \& Frewer, 2012).

Also, a label is an effective way to deliver an instant message on quality assurance, which was mandated by the government of Vietnam, as in the European Union or the United States (Roosen et al., 2003). In contrast, price and product certification had a negative impact on traceability adoption. The results found that price was as expected (Lu et al., 2016; Ortega et al., 2016; Wu et al., 2016), however, the negative effect of certification seemed to be counterintuitive. In Western countries, consumers often express high confidence in government and/or independent private certification (Christensen et al., 2003; Hobbs et al., 2005). In China, for example, a country that mostly resembles Vietnam, the impact of certification was inconsistent among studies and depended greatly on the perception of consumers toward specific types of certification. As Ortega et al. (2016) found, consumers' poor understanding related to Green Food and Organic certification was reflected via negative coefficients. On the contrary, Wu et al. (2015), Lu et al. (2016), and Wu et al. (2016) found the complete opposite result - that certification, specifically government certification, was most preferred by consumers.

In the case of Vietnam, the negative impact of certification can be explained via low trust of government certification (Ifft et al., 2009a, 2009b), as well as supported by the negative perception of food safety. Models 1 and 2 both recommended the strongest effect of freshness, which positively impacted the adoption of traceble products. The probability of traceability adoption increased by $35.7 \%$ and $48.1 \%$ for a one-unit increase in freshness for models 1 and 2, respectively. Freshness was highly valuable to consumers in terms of appearance. This was similar to findings that consumers tend to judge food quality via its appearance (Đỗ Kim Chung \& Nguyễn Linh Trung, 2015; Wu et al., 2015; Lu et al., 2016). Moreover, the adoption of traceable products will increase $3.3 \%$ with one unit increase in traceability. The positive effect of traceability was as expected, in accordance with many traceability studies (van Rijswijk \& Frewer, 2012; Lu et al., 2016). The results indicate that 
the probability of adoption increased by 3.3\% for a one-unit increased in traceability. Furthermore, know QR code had a positive effect on traceability adoption. As expected, the more consumers understand the QR code, a communication channel of traceability, the more likely they will opt for traceable products, at a higher estimated probability of $3.8 \%$, and $3.9 \%$ from models 1 and 2, respectively.

Consumers characteristics also affect the adoption of traceability and understanding of safety-related attributes. In model 1, the results revealed that gender, age, marital status, education, main shopper, monthly income, safety perception, and know QR code impacted consumers decisions for traceable products, while children under 18 did not. For age and education, the negative effect of age and the positive effect of education can be explained that younger consumers with more education level tended to opt for traceability attributes, which was in accordance with Wu et al. (2015) and Lu et al. (2016). Moreover, customers with higher income have higher preferences and a probability of $2.7 \%$ higher chance opting for certified traceable food. This result was in line with many studies (Gracia et al., 2011; Wu et al., 2017).

The probability of male consumers adopting certified traceable food was $6.3 \%$ higher than their female counterpart. The result found from gender was suitable with the negative sign for main shoppers, who majorly were women. Main shoppers had the probability of $6.3 \%$ lesser to adopt products with safety attributes. The reality reinforced this finding, as female consumers (especially main shoppers) have more experience. Thus, they were likely to rely on their own judgement, while their male counterparts made decisions on provided information. Next, model 1 resulted in the positive sign of marital status indicated that married consumers were more likely to select certified traceable products than single consumers at $11.4 \%$ higher probability. The probability was estimated even higher for model 2 at $32.9 \%$. This result was reasonable as married people take food safety more seriously due to their responsibility to other family members rather than just themselves.

Wu et al. (2011) revealed that the more consumers concern food scares, the more likely they will demand safety assurance information. Thus, a food traceability system is a very potential option to transmit such information formally. However, this study found contrasting results. The negative sign of safety perception indicated that the more consumers concern safety issues, the more likely they will opt for traceable food. This was closely linked to the culture and current context of Vietnam, which greatly differed from the developed world. Lots of media channels reported that farmers often split their crop in two parts, one for sale and one for home consumption. The home-consumption produces are labeled as safe for self-sufficient need compared to the one for sale, which often contains pesticide overdose. This widely known incident worsens consumers' perception of safe food. Furthermore, government failures of controlling food safety issues and counterfeit governmental certifications backed consumers into the corner. This explained why consumers sought out for a safer food option and often counted on their own judgement of the appearance of the produces which usually associated with product quality, in accordance with the false belief that freshness meant quality. This was consistent with our 
finding as freshness stayed the most important factor in purchasing decision regarding certified traceable food.

For interaction terms, model 2 resulted in only 2 variables that statistically significant at $1 \%$, of which the positive sign of safety perception with price indicated that consumers who's concerned about food safety would associate traceable products with higher price, which confirmed the finding of Röhr et al. (2005). In other words, consumers were willing to pay more for traceable products in the context of food safety issue. Meanwhile, the negative sign of safety perception with freshness was consistent with the effects of other variables. The bigger concerns consumers have over food safety issues, the more likely they will demand fresher produces.

The consistency of respondents was checked using the Pearson chi square test. The estimated Pearson correlation coefficient between main profiles and holdouts was relatively moderate, 0.377, which indicated that respondents were fairly consistent with their selections.

\section{Table 5.}

Model results with calculated marginal effects

\begin{tabular}{|c|c|c|c|c|c|c|}
\hline \multirow[t]{2}{*}{ Variable } & \multicolumn{3}{|c|}{ Model 1} & \multicolumn{3}{|c|}{ Model 2} \\
\hline & Coefficient & $\begin{array}{c}\text { Marginal } \\
\text { effect }\end{array}$ & $\begin{array}{c}\text { Standard } \\
\text { error }^{\dagger}\end{array}$ & Coefficient & $\begin{array}{c}\text { Marginal } \\
\text { effect }\end{array}$ & $\begin{array}{c}\text { Standard } \\
\text { error }^{\dagger}\end{array}$ \\
\hline Constant & 0.216 & & & 1.292 & & \\
\hline \multicolumn{7}{|l|}{ Attribute } \\
\hline Price & $-0.000^{* \star *}$ & -0.000 & 0.000 & $-0.000^{* * *}$ & -0.000 & 0.000 \\
\hline Label & $0.388^{* * *}$ & 0.150 & 0.054 & $0.361^{* * *}$ & 0.140 & 0.138 \\
\hline Certification & $-0.060^{* * *}$ & -0.023 & 0.031 & -0.168 & -0.064 & 0.226 \\
\hline Freshness & $0.934^{* * *}$ & 0.357 & 0.054 & $1.293^{* * *}$ & 0.481 & 0.137 \\
\hline Traceability & $0.088^{* * *}$ & 0.033 & 0.031 & 0.113 & 0.043 & 0.227 \\
\hline \multicolumn{7}{|l|}{ Socio-demographic } \\
\hline Gender & $0.166^{* * *}$ & 0.063 & 0.072 & 0.265 & 0.099 & 0.264 \\
\hline Age & $-0.240^{* \star *}$ & -0.092 & 0.045 & $-0.494^{\star \star *}$ & -0.189 & 0.162 \\
\hline Marital status & $0.299^{* * *}$ & 0.114 & 0.088 & $0.885^{* \star *}$ & 0.329 & 0.323 \\
\hline Education & $0.082^{* * *}$ & 0.031 & 0.039 & 0.146 & 0.056 & 0.141 \\
\hline Main shopper & $-0.164^{* * *}$ & -0.063 & 0.065 & -0.295 & -0.112 & 0.236 \\
\hline $\begin{array}{l}\text { Children under } 18 \\
\text { (under 18) }\end{array}$ & -0.090 & -0.034 & 0.065 & -0.223 & -0.085 & 0.238 \\
\hline Monthly income & $0.072^{* * *}$ & 0.027 & 0.022 & -0.039 & -0.015 & 0.079 \\
\hline Safety perception & $-0.113^{* * *}$ & -0.043 & 0.027 & $-0.368^{*}$ & -0.141 & 0.205 \\
\hline
\end{tabular}




\begin{tabular}{|c|c|c|c|c|c|c|}
\hline \multirow[t]{2}{*}{ Variable } & \multicolumn{3}{|c|}{ Model 1} & \multicolumn{3}{|c|}{ Model 2} \\
\hline & Coefficient & $\begin{array}{c}\text { Marginal } \\
\text { effect }\end{array}$ & $\begin{array}{c}\text { Standard } \\
\text { error }^{\dagger}\end{array}$ & Coefficient & $\begin{array}{c}\text { Marginal } \\
\text { effect }\end{array}$ & $\begin{array}{c}\text { Standard } \\
\text { error }^{\dagger}\end{array}$ \\
\hline Know QR code & $0.100^{* * *}$ & 0.038 & 0.053 & $0.102^{\star * *}$ & 0.039 & 0.053 \\
\hline \multicolumn{7}{|l|}{ Interaction terms } \\
\hline Traceability*gender & & & & -0.040 & -0.015 & 0.089 \\
\hline Traceability*age & & & & -0.055 & -0.021 & 0.055 \\
\hline Traceability*marital status & & & & -0.137 & -0.052 & 0.109 \\
\hline Traceability*education & & & & -0.004 & 0.001 & 0.048 \\
\hline Traceability*main shopper & & & & -0.019 & -0.007 & 0.080 \\
\hline Traceability*under 18 & & & & -0.026 & -0.010 & 0.081 \\
\hline Traceability*income & & & & 0.013 & 0.005 & 0.026 \\
\hline Certification ${ }^{*}$ gender & & & & -0.009 & -0.003 & 0.088 \\
\hline Certification*age & & & & 0.067 & 0.026 & 0.055 \\
\hline Certification*marital status & & & & -0.152 & -0.058 & 0.108 \\
\hline Certification*education & & & & -0.036 & -0.014 & 0.048 \\
\hline Certification*main shopper & & & & 0.084 & 0.032 & 0.079 \\
\hline Certification*under 18 & & & & 0.090 & -0.034 & 0.080 \\
\hline Certification*income & & & & 0.041 & 0.016 & 0.026 \\
\hline Safety perception* price & & & & $0.000^{* * *}$ & 0.000 & 0.000 \\
\hline Safety perception*label & & & & -0.012 & 0.004 & 0.053 \\
\hline $\begin{array}{l}\text { Safety } \\
\text { perception*certification }\end{array}$ & & & & -0.015 & -0.005 & 0.033 \\
\hline Safety perception*freshness & & & & $-0.148^{* * *}$ & -0.057 & 0.053 \\
\hline $\begin{array}{l}\text { Safety } \\
\text { perception*traceability }\end{array}$ & & & & -0.041 & -0.015 & 0.033 \\
\hline Log-likelihood & -1590.88 & & & -1575.68 & & \\
\hline LR chi2 & $462^{* * *}$ & & & $492.4^{\star \star *}$ & & \\
\hline Pseudo-R² & 0.126 & & & 0.135 & & \\
\hline Prediction probability $(\mathrm{Y}=1)$ & $60.6 \%$ & & & $60.8 \%$ & & \\
\hline Overall corrected predicted & $69 \%$ & & & $69.26 \%$ & & \\
\hline Total no. observations & 2,700 & & & 2,700 & & \\
\hline
\end{tabular}

Note: *** ,**, * values indicate statistically significance at $1 \%, 5 \%$, and $10 \%$ respectively.

†Standard errors of corresponding coefficient 


\section{Conclusions}

In this study, 150 consumers in Ho Chi Minh City, Vietnam were surveyed to investigate consumer preferences for traceable fresh produce (i.e. water spinach) in the context of food safety issues. The study used choice experiment to explore factors affecting consumer purchasing decisions related to food safety attributes and their perception over traceability attributes.

Results suggested that the negative food context of Vietnam did affect positively to the adoption of certified traceable food from Vietnamese consumers. Besides opting for a solution such as food traceability systems, Vietnamese consumers also adhered food quality to food appearance (i.e. freshness) and made judgement with such perception. Additionally, the odds of selecting traceable safe food were in favor of lower levels of certificates. This finding contributed to what scholars found in developed countries. This argument can be explained by low trust in the government, the impact of current food safety issues, and the false perception of food safety.

The impact of safety-related attributes goes in the order of decreasing magnitude: freshness, label, traceability, certification, and price. Beside the importance of freshness, consumers prefered a product with a label rather than a product with none. Moreover, the impact of detail information of traceability was insignificant in comparison with the impact of label. Based on recommendation of Roosen et al. (2003) and Giraud and Halawany (2006), the results of this study also suggested that traceability information should be delivered via food label as precise and concise as possible due to consumers need for visual inspection. Regarding price, consumers associated traceable products with higher prices and were willing to pay extra for traceability attributes, this would create incentives for suppliers to be loyal to the traceability path.

The social demographic characteristics of respondents also helped to portrait potential adopters as well as suggesting policy implications to widespread food traceability systems in the public. A potential adopter of certified traceable food is characterized as middle-age and below (age preferrably 35 and below), married, having a reasonable income, possessing high education level. Individuals with high education level and income tend to be interested in trying new things. As such, food retailers of all types should target this customer segmentation for traceable products with a policy that facilitates their purchasing decisions.

\section{Policy Implications}

Low trust is the biggest problem barricading the development of food traceability systems. To enhance consumer confidence, the government could implement a diverse course of action. First, the government must strengthen the implementation aspect along with current legislative frameworks. Government supervision via intensive market inspection needs to be in place to iron out food violations and frauds related to government 
certification (Wu et al., 2016). Violation of food safety law must subject to severe punishment as an example to the others. In parallel with market inspection, market education proved to be effective in related negative incidents, in accordance with microeconomic theories. Accordingly, extensive public propaganda is a useful way to draw consumer's attention to traceability measures (Verbeke \& Ward, 2006; Jin \& Zhou, 2014). The more consumers are aware of the existence of a solution to food safety issues, the more probability they will adopt the practice for their own safety assurance.

Consumers value freshness. Therefore, the government should employ a comprehensive policy instruments to facilitate the transfer of modern post-harvest technology from research institutes and universities to help producers of traceable food to maintain a high level of freshness for their produces. Moreover, the government should play a significant role in cultivating markets for traceable food in order to gradually increase the exposure of traceable foods to the community. Changing consumers' purchasing habit is a long-term plan that requires substantial endeavors with different approaches to ensure the result.

\section{Limitation}

There are three notable limitations in this study. First, the study only investigated the impact of factors based on variable levels. Further investigation on the impact of different attribute levels would elicit more useful details as not all attribute levels would be statistically significant and contribute to the knowledge of consumers' preferences as a whole (see examples: Ortega et al., 2016; Wu et al., 2012). Second, the study was conducted on citizens of Ho Chi Minh city, which was hard to be representative of Vietnamese population. Thus, future studies should consider a more representative sample of Vietnam. Third, our sample commodity used in this study was water spinach, intended to use instead of meat to study consumer preferences for fresh produces. Van Rijswijk and Frewer (2012) suggested that consumer preferences may vary for different products. For that reason, further studies with different sample commodities may give more insights into consumers' preferences.

\section{Acknowledgements}

All consumers, supervisors, and managers of the supermarkets and convenient stores who participated and facilitated the survey are gratefully acknowledged. We are also grateful for insightful comments of two anonymous reviewers. We also would like to express special thanks to Mr. John Maceda for proofreading and editing language for the paper.

Funding: This research did not receive any specific grant from funding agencies in the public, commercial, or not-for-profit sectors. 


\section{References}

Addelman, S. (1972). Recent developments in the design of factorial experiments. Journal of the American Statistical Association, 67(337), 103-111.

Angulo, A. M., Gil, J. M., \& Tamburo, L. (2005). Food safety and consumers' willingness to pay for labelled beef in Spain. Journal of Food Products Marketing, 11(3), 89-105.

Bateman, I. J., Carson, R. T., Day, B., Hanemann, M., Hanleys, N., Hett, T., Jones-Lee, M., Loomes, G., Mourato, S., Ozdemiroglu, E., Pearce, D. W., Sugden, R. \& Swanson, J. (2002). Economic Valuation with Stated Preference Techniques: A Manual. Cheltenham, UK: Edward Elgar Publishing.

Carlsson, F., Frykblom, P., \& Lagerkvist, C. J. (2007). Preferences with and without prices Does the price attribute affect behavior in stated preference surveys?. Environmental and Resource Economics, 38(2), 155-164.

Chen, T., Chen, M., \& Kiyohide, M. (2015). Impact of food safety incident on consumers' willingness to pay: The case of China. Journal of Integrated Field Science, 12, 53-58.

Christensen, B. J., Bailey, D., Hunnicutt, L., \& Ward, R. A. (2003). Consumer preferences for public and private sector certifications of beef products in the United States and the United Kingdom. International Food and Agribusiness Management Review, 6(3), 19-39.

de-Magistris, T., \& Gracia, A. (2016). Consumers' willingness-to-pay for sustainable food products: The case of organically and locally grown almonds in Spain. Journal of Cleaner Production, 118, 97-104.

de-Magistris, T., \& Gracia, A. (2014). Do consumers care about organic and distance labels? An empirical analysis in Spain. International Journal of Consumer Studies, 38(6), 660-669.

Dickinson, D. L., \& Bailey, D. (2002). Meat traceability: Are US consumers willing to pay for it?. Journal of Agricultural and Resource Economics, 27(2), 348-364.

European Parliament. (2002). Regulation (EC) No. 178/2002 of the European Parliament and of the Council. Official Journal of the European Communities, L31/1-L31/24.

Fahrion, A. S., Lapar, M. L., Nguyen, N.T., Do, N. T., \& Grace, D. (2013). Food-borne hazards in a transforming pork value chain in Hanoi: Basis for future risk assessments. Vietnamese Journal of Preventive Medicine, 23(4), 18-25.

Gellynck, X., \& Verbeke, W. (2001). Consumer perception of traceability in the meat chain. Agrarwirtschaft, 50(6), 368-373.

Giraud, G., \& Halawany, R. (2006). Consumers' perception of food traceability in Europe. In Proceedings of the 98th EAAE Seminar: Marketing Dynamics within the Global Trading System (pp.1-9). Chania, Greece: EAAE.

Golan, E. H., Krissoff, B., Kuchler, F., Calvin, L., Nelson, K., \& Price, G. (2004). Traceability in the US food supply: Economic theory and industry studies. Agricultural Economic Report Number 830. Retrieved from: https:/ / ageconsearch.umn.edu/record/33939/ 
Government. (1999). Decision No. 178/1999/QD-TTg dated Aug 30, 1999 promulgating the regulation on the labeling of goods to be circulated in the country and export as well as import goods. Retrieved from: https://thuvienphapluat.vn/van-ban/Thuong-mai/178-1999QD-TTg-78979.aspx

Government. (2017). Decree 43/2017/ND-CP dated Apr 14, 2017 on good labels. Retrieved from: https://thuvienphapluat.vn/van-ban/Thuong-mai/Decree-43-2017-ND-CP-on-goodlabels-348247.aspx

Gracia, A. (2014). Consumers' preferences for a local food product: A real choice experiment. Empirical Economics, 47(1), 111-128.

Gracia, A., Loureiro, M. L., \& Nayga, J. R. M. (2011). Are valuations from nonhypothetical choice experiments different from those of experimental auctions?. American Journal of Agricultural Economics, 93(5), 1358-1373.

GSO. (2016). Kết quả tổng điều tra Nông thôn, Nông nghiệp và Thủy sản năm 2016. Retrieved from: https:/ / www.gso.gov.vn/default_en.aspx?tabid=515\&idmid=5\&ItemID=18966

Hobbs, J. E., Bailey, D., Dickinson, D. L., \& Haghiri, M. (2005). Traceability in the Canadian red meat sector: do consumers care? Canadian Journal of Agricultural Economics/Revue Canadienne D'agroeconomie, 53(1), 47-65.

Ifft, J., Otte, J., Roland-Holst, D., \& Zilberman, D. (2009a). Poultry certification for pro-poor HPAI risk reduction. Mekong Team Working Paper No. 6, Pro-poor HPAI risk reduction project.

Retrieved

from

https://www.academia.edu/1019770/Poultry_Certification_for_ProPoor_HPAI_Risk_Reduction

Ifft, J., Roland-Holst, D., \& Zilberman, D. (2009b). Valuation of safety-branded and traceable free range chicken in Ha Noi: Results from a field experiment. In Proceedings of the Agricultural \& Applied Economics Association 2009 AAEA \& ACCI Joint Annual Meeting. Milwaukee, Wisconsin, USA.

Jin, S., Zhang, Y., \& Xu, Y. (2017). Amount of information and the willingness of consumers to pay for food traceability in China. Food Control, 77, 163-170.

Jin, S., \& Zhou, L. (2014). Consumer interest in information provided by food traceability systems in Japan. Food Quality and Preference, 36, 144-152.

Đỗ Kim Chung, \& Nguyễn Linh Trung. (2015). Sự lựa chọn của người mua rau tại chợ và siêu thị trên địa bàn thành phố Hà Nội. Tạp chí Khoa học và Phát triển, 13(2), 308-315.

Lancaster, K. J. (1966). A new approach to consumer theory. Journal of Political Economy, 74(2), 132-157.

Liao, P.-A., Chang, H.-H., \& Chang, C.-Y. (2011). Why is the food traceability system unsuccessful in Taiwan? Empirical evidence from a national survey of fruit and vegetable farmers. Food Policy, 36(5), 686-693. 
Loureiro, M. L., \& Umberger, W. J. (2007). A choice experiment model for beef: What US consumer responses tell us about relative preferences for food safety, country-of-origin labeling and traceability. Food Policy, 32(4), 496-514.

Louviere, J. J., Hensher, D. A., \& Swait, J. D. (2000). Stated Choice Methods: Analysis and Applications. Cambridge: Cambridge University Press.

Lu, J., Wu, L., Wang, S., \& Xu, L. (2016). Consumer preference and demand for traceable food attributes. British Food Journal, 118(9), 2140-2156.

Luce, R. D. (1959). Individual Choice Behavior: A Theoretical Analysis. New York: Wiley.

MARD. (2011a). Circular 74/2011/TT-BNNPTNT dated Oct 31, 2011 on traceability, recall and handling of unsafe agricultural and forest food. Retrieved from: https://thuvienphapluat.vn/van-ban/the-thao-y-te/Circular-No-74-2011-TTBNNPTNT-on-traceability-recall-and-handling-of-unsafe-133422.aspx

MARD. (2011b). Circular 03/2011/TT-BNNPTNT dated Jan 21, 2011 on tracing and recall of fishery products failing to meet food quality and safety requirements. Retrieved from: https:/ / thuvienphapluat.vn/van-ban/Linh-vuc-khac/Circular-No-03-2011-TTBNNPTNT-on-tracing-and-recall-of-fishery-products-faili-122850.aspx

MARD. (2017). Circular No. 11/2017/TT-BNNPTNT dated May 29, 2017 on amendments to some articles of legislative documents relating to functions and tasks of units affiliated to the Ministry of Agriculture and Rural Development. Retrieved from: https:/ / thuvienphapluat.vn/vanban/bo-may-hanh-chinh/circular-11-2017-tt-bnnptnt-amendments-documentsrelating-functions-and-tasks-of-units-affiliated-368989.aspx

McFadden, D.(1973). Conditional logit analysis of qualitative choice behavior. In P. Zarembka (Ed.), Frontiers of Econometrics (pp. 105-142). New York: Academic Press.

Mørkbak, M. R., Christensen, T., \& Gyrd-Hansen, D. (2010). Choke price bias in choice experiments. Environmental and Resource Economics, 45(4), 537-551.

Ngoc, P. T. A., Meuwissen, M. P. M., Le, T. C., Bosma, R. H., Verreth, J., \& Lansink, A. O. (2016). Adoption of recirculating aquaculture systems in large pangasius farms: A choice experiment. Aquaculture, 460, 90-97.

Nguyen-Viet, H., Tuyet-Hanh, T. T., Unger, F., Dang-Xuan, S., \& Grace, D. (2017). Food safety in Vietnam: Where we are at and what we can learn from international experiences. Infectious Diseases of Poverty, 6, 39.

Ortega, D. L., Hong, S. J., Wang, H. H., \& Wu, L. (2016). Emerging markets for imported beef in China: Results from a consumer choice experiment in Beijing. Meat Science, 121, 317-323.

Ortega, D. L., Wang, H. H., Wu, L., \& Olynk, N. J. (2011). Modeling heterogeneity in consumer preferences for select food safety attributes in China. Food Policy, 36(2), 318-324.

Regattieri, A., Gamberi, M., \& Manzini, R. (2007). Traceability of food products: General framework and experimental evidence. Journal of Food Engineering, 81(2), 347-356. 
Röhr, A., Lüddecke, K., Drusch, S., Müller, M. J., \& Alvensleben, R. v. (2005). Food quality and safety--consumer perception and public health concern. Food Control, 16(8), 649-655.

Roosen, J., Lusk, J. L., \& Fox, J. A. (2003). Consumer demand for and attitudes toward alternative beef labeling strategies in France, Germany, and the UK. Agribusiness: An International Journal, 19(1), 77-90.

van Rijswijk, W., \& Frewer, L. J. (2008). Consumer perceptions of food quality and safety and their relation to traceability. British Food Journal, 110(10), 1034-1046.

van Rijswijk, W., \& Frewer, L. J. (2012). Consumer needs and requirements for food and ingredient traceability information. International Journal of Consumer Studies, 36(3), 282-290.

van Rijswijk, W., Frewer, L. J., Menozzi, D., \& Faioli, G. (2008). Consumer perceptions of traceability: A cross-national comparison of the associated benefits. Food Quality and Preference, 19(5), 452-464.

Verbeke, W. (2001). The emerging role of traceability and information in demand-oriented livestock production. Outlook on Agriculture, 30(4), 249-255.

Verbeke, W., \& Ward, R. W. (2006). Consumer interest in information cues denoting quality, traceability and origin: An application of ordered probit models to beef labels. Food Quality and Preference, 17(6), 453-467.

Viaene, J., Verbeke, W., \& Gellynck, X. (2000). Quality perception of vegetables by Belgian consumers. Acta Horticulturae, 524, 89-96.

Wertheim-Heck, S. C., Vellema, S., \& Spaargaren, G. (2015). Food safety and urban food markets in Vietnam: The need for flexible and customized retail modernization policies. Food Policy, 54, 95-106.

World Bank. (2017a). Vietnam Food Safety Risks Management: Challenges and Opportunities: Technical working paper (English). Retrieved from: http:/ / documents.worldbank.org/curated/en/415551490718806138/technicalworking-paper

World Bank. (2017b). Vietnam Food Safety Risks Management: Challenges and Opportunities (Vol. 2): Annexes (English). Retrieved from: http://documents.worldbank.org/curated/en/608361490883434649/ Annexes

Wu, L., Gong, X., Qin, S., Chen, X., Zhu, D., Hu, W., \& Li, Q. (2017). Consumer preferences for pork attributes related to traceability, information certification, and origin labeling: Based on China's Jiangsu Province. Agribusiness, 33(3), 424-442.

Wu, L., Wang, H., Zhu, D., Hu, W., \& Wang, S. (2016). Chinese consumers' willingness to pay for pork traceability information - the case of Wuxi. Agricultural Economics, 47(1), 71-79.

Wu, L., Wang, S., Zhu, D., Hu, W., \& Wang, H. (2015). Chinese consumers' preferences and willingness to pay for traceable food quality and safety attributes: The case of pork. China Economic Review, 35, 121-136. 
Wu, L., Xu, L., \& Gao, J. (2011). The acceptability of certified traceable food among Chinese consumers. British Food Journal, 113(4), 519-534.

Wu, L., Xu, L., Zhu, D., \& Wang, X. (2012). Factors affecting consumer willingness to pay for certified traceable food in Jiangsu Province of China. Canadian Journal of Agricultural Economics/Revue Canadienne D'agroeconomie, 60(3), 317-333. 